\title{
Rootzone salinity monitoring and management in Acacia ampliceps irrigated with three water salinity levels in Entisols of United Arab Emirates
}

\author{
Khalil Ur Rahman ${ }^{1 \star} \bullet$ Ramachandran Subramanian $^{1} \bullet$ Shabbir Ahmad Shahid ${ }^{2} \bullet$ Shoaib Ismail $^{2}$ \\ ${ }^{1}$ BITS Pilani, Dubai Campus, Dubai International Academic City, United Arab Emirates. \\ ${ }^{2}$ International Center for Biosaline Agriculture, Dubai, United Arab Emirates. \\ ${ }^{*}$ Corresponding author. E-mail: krbutt@emirates.net.ae
}

Accepted 23 $3^{\text {rd }}$ April, 2019.

\begin{abstract}
A three years (2014-2016) trial was conducted at the experimental station of Dubai based International Center for Biosaline Agriculture. The objective of this project was to assess the adoptability of $A$. ampliceps trees in sandy desert conditions by irrigating with three water salinities (ECiw 10, 20, $30 \mathrm{dS} / \mathrm{m}$ ). Bubler irrigation system was used to irrigate the trees in basins. Soil salinity (electrical conductivity of soil saturation extract-ECe) was assessed at two depths ( 0 to 25 and 25 to $50 \mathrm{~cm}$ ) over a period of three years. Root zone salinity was the lowest in 2014 and the highest in 2016. The root zone salinity at both depths in the years 2014, 2015 and 2016 was higher than the irrigation water salinity $(E C i w=10 \mathrm{dS} / \mathrm{m})$. Salinity at both depths was almost similar where same irrigation water was used. The soil salinity was less than the water salinity of the respective irrigation waters (20 and $30 \mathrm{dS} / \mathrm{m}$ ) during 2014, revealing soil salinity is well managed. In contrary to 2014, during 2015 and 2016 the soil salinities of the trees irrigated with water salinities of 20 and $30 \mathrm{dS} / \mathrm{m}$ were higher than the irrigation water salinities. The results reveal that it is possible to manage salinity during first year compared with subsequent years. The soil salinity with the application of fertilizer is insignificantly higher but within the range of standard deviation. Among two salinity assessment scenarios, the scenario ECe/ECiw > 1.5 fits well to assess salinity management efforts in sandy soil conditions.
\end{abstract}

Keywords: Sandy soil, desert condition, A. ampliceps, salinity management, typic torripsamments.

\section{INTRODUCTION}

In hot hyper-arid environment of the United Arab Emirates, the major constraints to agriculture production are arable land, water scarcities and ground water salinity. The fresh water scarcity necessitates the use of saline/brackish water under desert conditions (Pasternak et al., 1993) to offset water requirements of crops. The mismanagement of such a high salinity water may result into soil salinization to a level where agricultural farms are abandoned due to low productivity leading to uneconomical returns. Historical perspectives of soil salinization have been presented by Shahid et al. (2018c). Recently Shahid et al. (2010) have hypothesized salinity development cycle to describe the sequence of soil salinity development, including various facets, such as leaching, seepage from irrigation system, water movement restriction, capillary rise, and evaporation to salts crystallization. The United Nations UniversityInstitute for Water, Environment and Health (UNU-INWEH, 2014) states that irrigated lands cover some 310 million hectares, an estimated 20 percent (UNU-INWEH, 2014) 
of it is affected by salinity and sodicity (62 million hectares) yielding an estimate of global economic losses at US\$27.3 billion per year (Qadir et al., 2014). It further states that every day for more than 20 years, an average of 2,000 hectares of irrigated land in arid and semi-arid areas across 75 countries have been degraded by salt (UNU-INWEH). Where the soil salinity is widespread such as Australia a national action plan was implemented (Malcom, 1996).

Intensifying forage crop production to meet future demand would further cause enormous water stress in many countries. For example, in the Arabian Peninsula, expanded cultivation of alfalfa (Medicago sativa) and Rhodes grass (Chloris gayana) in response to the increased demand for livestock feed has resulted in a drastic reduction in groundwater levels and an increase in salinity due to seawater intrusion (Rao et al., 2017). Both these species require large quantities of water - from 15,700 to $48,000 \mathrm{~m}^{3} \mathrm{ha}^{-1} \mathrm{yr}^{-1}$ depending on soil and climate - often drawn from non-renewable groundwater sources (Peacock et al., 2003). The crops irrigated with saline/brackish waters cause soils to become saline, where salinity assessment helps understand current salinity level while monitoring determines periodic changes in soil salinity (Shahid et al., 2018b; Shahid and Rahman, 2011). Predicting root zone salinity is important to assure the root zone salinity is not reached above the threshold salinity level (Shahid et al., 2008, 2010, 2011).

In the context of the Middle East and North Africa (MENA) region, water scarcity is one of the most important food-security issues, with fresh water availability in the region expected to drop $50 \%$ by 2050 (World Bank, 2007) and the farming community will mostly rely on marginal quality water such as saline/brackish and treated sewage effluent (TSE), for the latter communities raise their concerns that it might cause diseases and may be used for selected crops where fruit is not in direct contact with water, where forages are devoid of this limitation. To minimize the effects of saline water on root-zone salinity, a suitable irrigation method must be selected, one which does not invoke soil salinity hazard (Zaman et al., 2018a, b). The extent of the salts variability depends on conditions such as differences in soil texture, growing plants, which transpire soil water and also absorb salt, quality of irrigation water, hydraulic conductivity, wetting zone and the type of irrigation system being used, etc. In agricultural fields, the irrigation through any modern irrigation system is unlikely be applied uniformly; therefore, the behavior of salinity development would be heterogeneous spatially at the farm level (Zaman et al., 2018a, b). The irrigation method chosen should be determined by the depth of irrigation, leaching, zones of salt accumulation, runoff, and the uniformity of applying the irrigation water.

To reduce the pressure on fresh water, nonconventional sources of water (saline and brackish water) will have to be tapped into to meet the needs of agriculture, especially in the dry areas. Therefore, other potential plants which are salt-tolerant and consumes less water should be considered as potential forages in the region, in this regards $A$. ampliceps among trees stands better. Multi-purpose $A$. ampliceps have the potential to form an integral component of Agricultural systems. Many decades of research and domestication has identified well adapted acacia species such as $A$. ampliceps. It grows rapidly, is well adapted to infertile soils, produce seeds that can be easily harvested and processed. They produce large quantities of fuel wood and construction timber, can be used as windbreaks, improve soil fertility (leguminous tree- $\mathrm{N}$ fixing) and may have a significant role as multi-purpose trees in sustainable Agroforestry systems. Considering the multipurpose benefits of $A$. ampliceps, this has been used in Agroforestry systems in various countries.

A three years (2014 to 2016) trial was conducted on salt-tolerant tree "A. ampliceps" with the objective to assess its performance under three different water salinity levels (ECiw 10, 20 and $30 \mathrm{dS} / \mathrm{m}$ ) and to monitor root zone salinity at two depths (0 to 25 and 25 to $50 \mathrm{~cm}$ ). Salinity assessment and monitoring helps understand the levels of salt accumulation in the root zone, whether below or above threshold level of crop in the field. The latter will require extra water to be applied based on the leaching fraction to maintain the root-zone salinity below crop threshold (Maas and Hoffman, 1977; Allen et al., 1998) salinity (salinity level where decrease in crop yield begins).

Once root-zone salinity is accumulated to a certain level (ECe $\geq 4 \mathrm{dS} / \mathrm{m}$; US Salinity Lab Staff, 1954) it becomes saline soil. Salinity is a measure of the concentration of all the soluble salts in soil or water as electrical conductivity (EC). By knowing water salinity of irrigation water and soil salinity at the seeding or planting stage, suitable salt-tolerant crops can be selected (Glenn et al., 1999) and those not suitable are eliminated from the list because increasing salinity levels reduce choice of crops. In extreme salinity cases "halophytes" can be used for forage and livestock production (Masters et al., 2007). Based on the salinity information decision is made which crops can be planted with a better understanding as how the specific crop might behave.

\section{Why A. ampliceps?}

Multi-purpose $A$. ampliceps have the potential to form an integral component of agricultural systems. Many decades of research and domestication has identified well adapted acacia species such as $A$. ampliceps. It grows rapidly, is well adapted to infertile soils, produce seeds that can be easily harvested and processed. They produce large quantities of fuel wood and construction timber, can be used as windbreaks, improve soil fertility (leguminous tree- $\mathrm{N}$ fixing) and may have a significant role 
Table 1. Physical and chemical characteristics of sandy soil at trial site.

\begin{tabular}{|c|c|c|c|c|c|c|c|c|c|c|c|c|}
\hline Depth & & $\mathrm{ECe}$ & SP & $\mathrm{CaCO}_{3}$ & BD & Porosity & OM & SAR & Sand & Silt & Clay & Taytural clace (I)ena) \\
\hline $\mathrm{cm}$ & & $d S / m$ & $\%$ & \%eq. & $\mathrm{g} / \mathrm{cm}^{3}$ & $\%$ & $\%$ & $(\text { mmoles/l/) })^{0.5}$ & $\%$ & $\%$ & $\%$ & extural ciass (USDA) \\
\hline $0-25$ & 8.11 & 0.74 & 24.61 & 54.60 & 1.63 & 39 & 0.40 & 3.00 & 98.0 & 1.0 & 1.0 & Sand \\
\hline $25-50$ & 8.52 & 0.73 & 24.50 & 57.80 & 1.62 & 39 & 0.23 & 5.20 & 97.0 & 1.5 & 1.5 & Sand \\
\hline
\end{tabular}

$\mathrm{BD}$ (bulk density); SP (saturation percentage); $\mathrm{pHs}$ ( $\mathrm{pH}$ of saturated soil paste); ECe (electrical conductivity of soil saturation extract); OM (organic matter); SAR (sodium adsorption ratio); OP (osmotic pressure); MC (moisture content)

as multi-purpose trees in sustainable Agroforestry systems. Considering the multipurpose benefits of $A$. ampliceps we trialed this tree by irrigating with three different water salinity levels $(10,20,30 \mathrm{dS} / \mathrm{m})$ over three years (2014 to 2016) in sandy soils of UAE "Entisols".

\section{Classes of soil salinity and plant growth}

Electrical conductivity of the soil saturation extract (ECe) is the standard measure of salinity. US Salinity Lab Staff (1954) has described general relationship of ECe and plant growth:

- Non saline (ECe 0-2 dS/m) - salinity effects mostly negligible

- Very slightly saline (ECe 2-4 dS/m) - yields of very sensitive crops may be restricted

- Slightly saline (ECe 4-8 dS/m) - yields of many crops are restricted

- Moderately saline (ECe 8-16 dS/m) - only salt tolerant crops exhibit satisfactory yields

- Strongly saline (ECe>16 dS/m) - only a few very salt tolerant crops show satisfactory yields

\section{MATERIALS AND METHODS}

The trial was conducted at the experimental station of Dubai based International Center for Biosaline Agriculture during three years (2014 to 2016). There exist three groundwater sources (ECiw 10, 20 and $30 \mathrm{dS} / \mathrm{m}$ ) those were used to irrigate $A$. ampliceps trees over three years period. In half of the trees fertilizer was used in others fertilizer was not use. The water salinity was monitored on a regular basis. The trial site belongs to soil order Entisols and soil taxonomic class is "Carbonatic, Hyperthermic, Typic torripsamments" based on US Soil taxonomy (Soil Survey Staff, 2014a; Shahid and Abdelfattah, 2008; Shahid et al., 2014). The soil texture was fine sand, with 97 to $99 \%$ sand, 1 to $2 \%$ silt and 0 to $1 \%$ clay (Soil Science Division Staff, 2017). Table 1 shows the analyses of the native sandy soil prior to the trial initiation. Native sandy soil is strongly calcareous, non-saline and non-sodic and the $\mathrm{pH}$ is in the range of moderately to strongly alkaline.

\section{Raising nursery of $\boldsymbol{A}$. ampliceps}

To initiate $A$. ampliceps plants, seeds were sown in $1 \mathrm{~L}$ volume plastic bags with hole at the bottom. A mixture of soil and compost (4:1 by volume) was prepared and properly mixed to have uniform mixture. The soil/compost mixture was added to plastic bags and one seed of $A$. ampliceps was placed at $1 \mathrm{~cm}$ depth in each pot and irrigated with fresh water. All seeds were germinated within 4 to 6 days. The pots were separated into three lots and the propagules in each lot were acclimatized for 8 weeks to finally accomplish irrigation with ECiw of 10, 20 and $30 \mathrm{dS} / \mathrm{m}$. The acclimatization took place in green house where final salinity achieved through stepwise increase of water salinity, e.g., final EC of $10 \mathrm{dS} / \mathrm{m}$ was reached from 2.5, 5 , and $10 \mathrm{dS} / \mathrm{m}$ over a period of 8 weeks, similarly EC 20 was achieved through 4 steps $(5,10,15$ and $20 \mathrm{dS} / \mathrm{m})$ and $30 \mathrm{dS} / \mathrm{m}$ $(5,10,20$ and $30 \mathrm{dS} / \mathrm{m})$.

\section{Transplantation of tress to trial sites}

Nine weeks old acclimatized trees were transplanted in the trial site. Tree to tree distance was 3 meters and line to line 5 meters. Prior to transplantation, pits of $50 \mathrm{~cm}$ wide and $50 \mathrm{~cm}$ deep were prepared as per trial layout plan. The pits were then filled with mixture of soil and compost (4:1 volume basis) and trees were transplanted. Half of the trees received eighty grams of compound 20:20:20 ( $\left.\mathrm{N}: \mathrm{P}_{2} \mathrm{O}_{5}: \mathrm{K}_{2} \mathrm{O}\right)$ fertilizer that was mixed with the upper $15 \mathrm{~cm}$ of soil surface in the pit once a year and pits were irrigated through bubler irrigation system using water salinity of 10,20 and 30 $\mathrm{dS} / \mathrm{m}$. The mature trees are shown in Figure 1.

\section{Basin irrigation system - Bubler system}

In basin irrigation, bunds are created around the circular basin to prevent the water flowing out, thus, confining the irrigation water to the target area. This method is commonly practiced for date palms and trees grown in small basins, with the tree being planted in the center of the basin. It should be kept in mind that the basin method is most suitable for sandy soils where water 

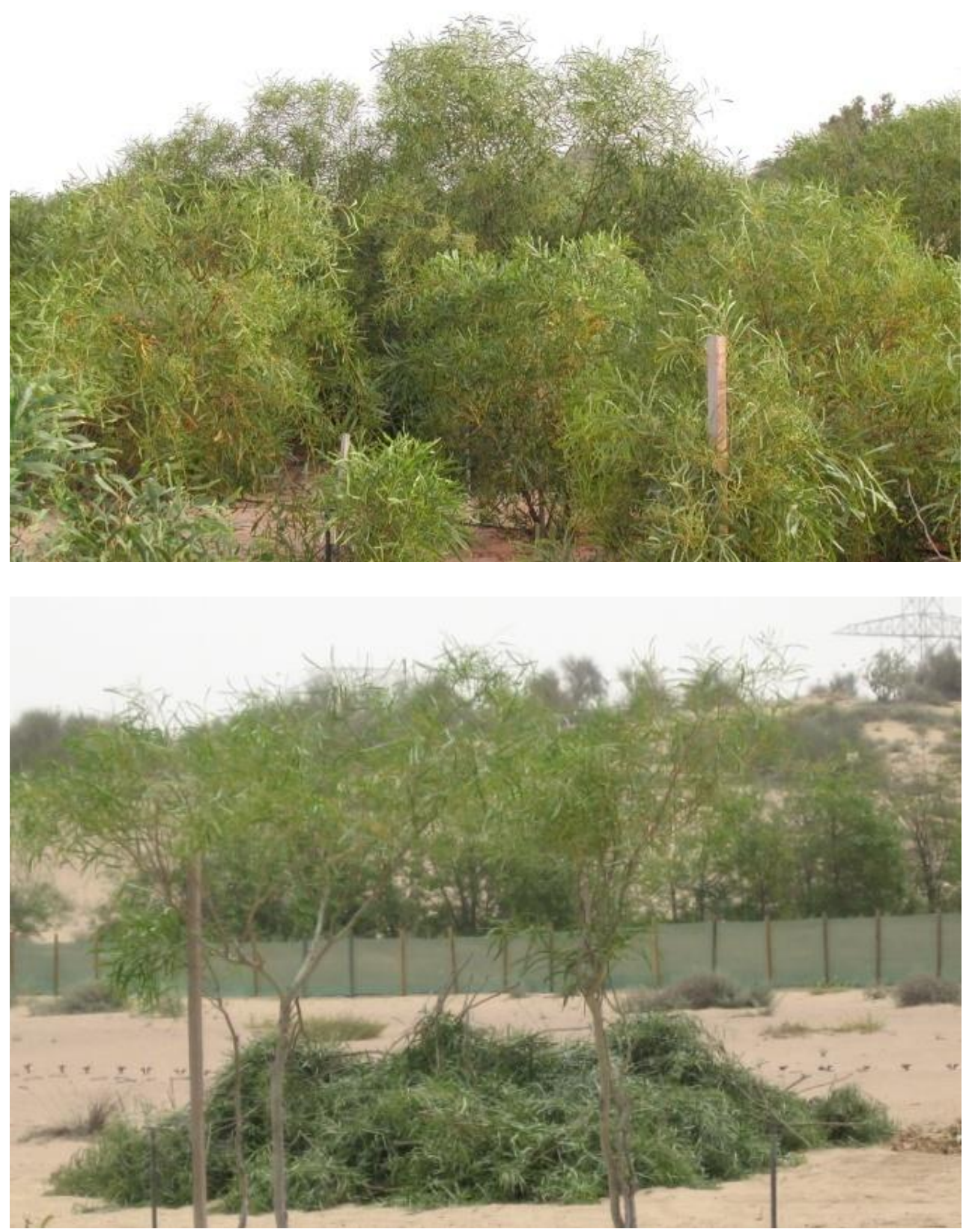

Figure 1. A. ampliceps in trial plot (top), pruned trees (bottom).

leaches down quickly. If the trees are sensitive to ponding water, this method should be avoided. In basin irrigation system, surface salinity is controlled, although at the subsurface wetting zone soil salinity will develop. In the basin a bubler is installed for irrigation which supplies water as circular water system. After transplantation each tree was irrigated through bubler irrigation system at the rate of 40 litres per day (one application) for the first four months. During the next 4 months (4 to 8 months) the irrigation volume was increased to 50 litres per tree and after 8 months the irrigation was increased to 60 liters per tree and continued till the trial completed in 2016 . The rainfall during three years was $21.64 \mathrm{~mm}$ (14 days), $18.15 \mathrm{~mm}$ (22 days) and $16.91 \mathrm{~mm}$ (28 days) per annum during 2014, 2015 and 2016 respectively (https://www.worldweatheronline.com/dubai-weatheraverages/dubai/ae.aspx).

\section{Soil salinity assessment}

Soil samples were collected from the tree basins using standard auger at two depths on a regular basis from all 


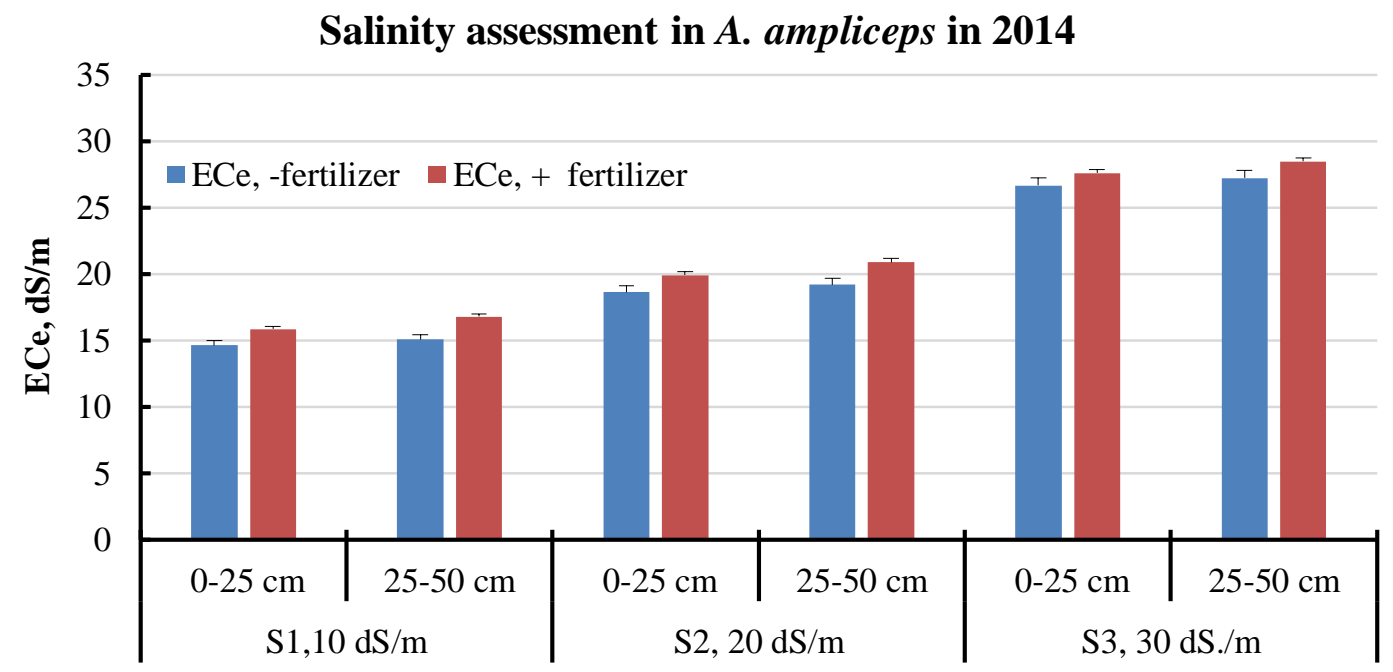

Water salinity levels

Figure 2. Comparative root-zone soil salinity at two depths with increasing irrigation water salinity and fertilizer application in the year 2014.

trees (12) irrigated with different water salinity $(10,120$, $30 \mathrm{dS} / \mathrm{m}$ ) levels. The soil samples were air-dried and processed to pass through $2 \mathrm{~mm}$ sieve prior to salinity analysis. The salinity assessment efforts have been made on both depths ( 0 to 25 and 25 to $50 \mathrm{~cm}$ ) and described in this paper. Saturated soil paste was prepared (Soil Survey Staff, 2014b) to collect extract under vacuum (saturation extract) and to measure EC. This measure, known as electrical conductivity of the soil saturation extract $(E C e)$, is now the generally accepted measure of soil salinity (US Salinity Lab Staff, 1954; Shahid, 2013; Shahid et al., 2018a, b; Soil Survey Staff 2014b). Each irrigation system develops salinity at a specific soil zone and thus needs to be carefully monitored. Recently (Shahid, 2014; Zaman et al., 2018a) zones of soil salinity development for a range of different irrigation systems have been described. In the current trial we used bubler irrigation system in tree basin.

\section{RESULTS AND DISCUSSION}

In this section, results of three years trial with focus on salinity development over three years (2014 to 2016) are presented. Based on the root zone salinity monitoring results over 3 years period following have been observed. It should be noted that biomass assessment was not the objective of this study which will be dealt in a separate paper.

\section{Salinity assessment of $A$. ampliceps}

Soil samples from 0 to 25 and 25 to $50 \mathrm{~cm}$ depths of $A$. ampliceps trees were collected and monitored over three years during $(2014,2015$ and 2016) and analyzed for EC of soil saturation extract $(\mathrm{ECe})$. The results ate presented in Figures 2, 3 and 4. Following are the observation from three years monitoring results.

Root zone salinity at both depths increased over a period of three years (Figures 2, 3 and 4); the lowest being recorded in 2014 (Figure 2) and the highest in 2016 (Figure 4). The surface ( 0 to 25 ) as well as subsurface $(25$ to $50 \mathrm{~cm}$ ) salinity is almost similar within the tree where same irrigation water was applied. Where difference occurs between soil salinity at two depths, it is insignificant and within standard deviation (SD) range. The root zone salinity levels at both depths in the years 2014, 2015 and 2016 are higher than the irrigation water salinity (ECiw $=10 \mathrm{dS} / \mathrm{m}$ ). During 2014 the soil salinity at both depths is lower than the water salinity of the respective irrigation waters $(20 \& 30 \mathrm{dS} / \mathrm{m})$, revealing salinity is well managed at higher irrigation water salinity during first year. In contrary to 2014, during 2015 and 2016 the soil salinities of the trees irrigated with water salinities of 20 and $30 \mathrm{dS} / \mathrm{m}$ were higher than the irrigation water salinity suggesting over years salinity has developed (Shahid et al., 2008, Shahid, 2013). The results clearly reveal that it is possible to manage salinity at early stage (during year 1 ) compared to subsequent years (2015 and 2016). The soil salinity with the application of fertilizer is slightly higher but within the range of standard deviation. This is true for all trees investigated.

\section{Assessment of root zone salinity management efforts}

We used two scenarios as proposed by Shahid et al. (2013) for light textured soils to assess the salinity 


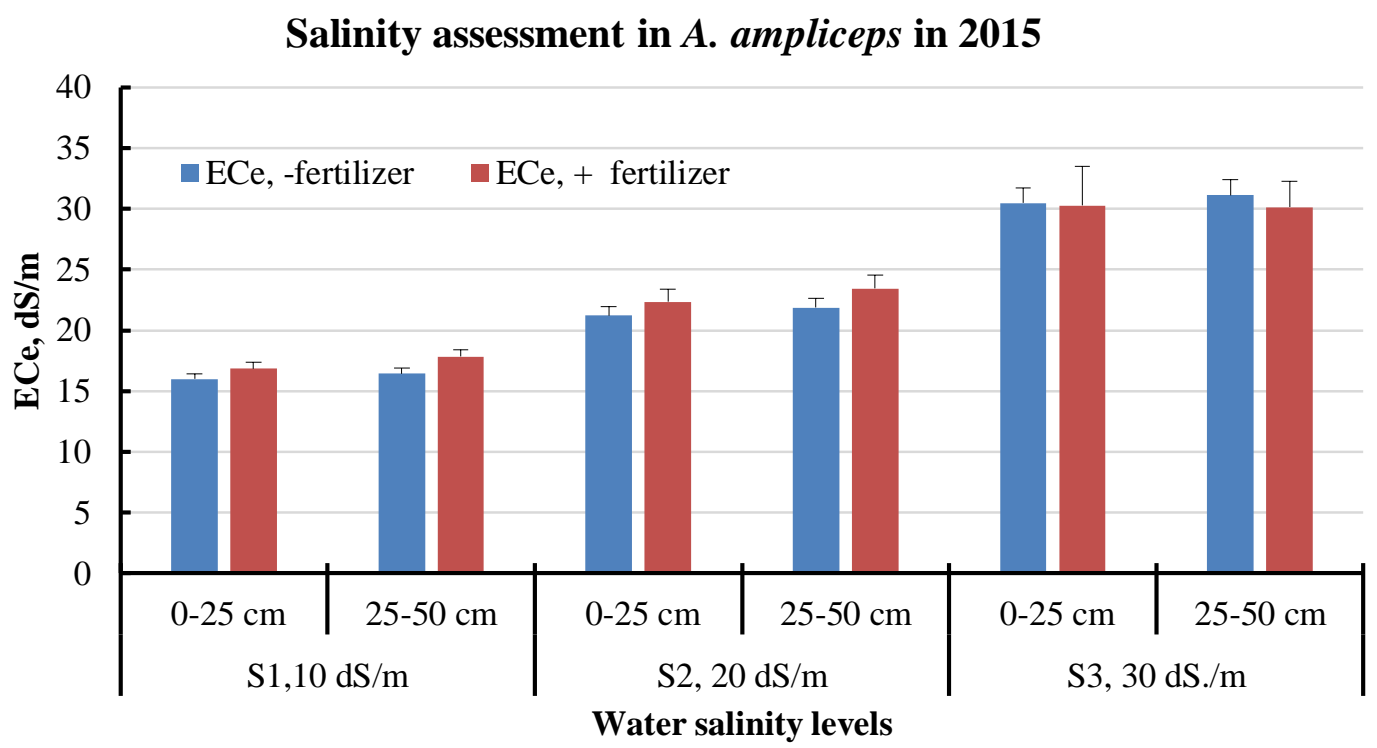

Figure 3. Comparative root zone-soil salinity at two depths with increasing irrigation water salinity and fertilizer application in the year 2015.

Salinity assessment in A. ampliceps in 2016

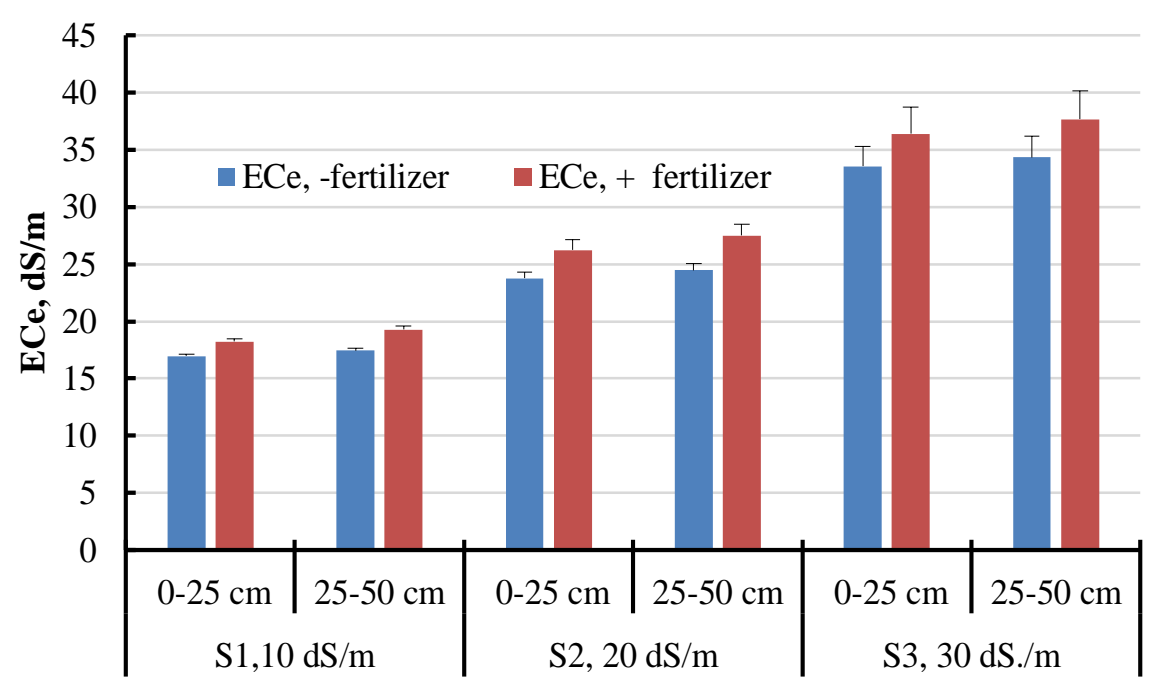

Water salinty levels

Figure 4. Comparative root-zone soil salinity at two depths with increasing irrigation water salinity and fertilizer application in the year 2016.

management efforts in the root zone.

\section{Scenario I}

To check salinity development in the root zone (ECe) in relation to irrigation water salinity (ECiw). The ratio between ECe/ECiw > 1.1 indicates poor salinity management indicating leaching fraction was not used properly.

\section{Scenario II}

The ratio between ECe/ECiw > 1.5 indicates poor salinity management indicating leaching fraction was not used properly.

The results of both scenarios are presented in Figures 5, 6 and 7 (ECe/ECiw > 1.1) and Figures 8, 9 and 10 (ECe/ECiw > 1.5). Following observations have been made. As described above that salinity management was better in 2014 compared to the next two years (2015 and 


\section{Tree rootzone salinity assessment in A. ampliceps trees} in 2014

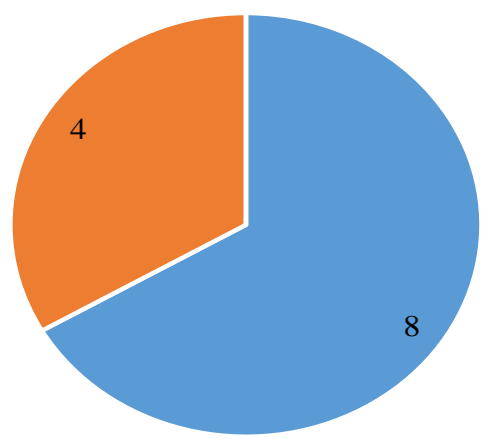

\section{ECe/ECiw}

$\because<1.1$

$\square>1.1$

Figure 5. Assessment of salinity management efforts in 2014 (ECe/ECiw $>1.1$ ) in A. ampliceps trees.

Tree rootzone salinity assessmentin in Acacia ampliceps in $\mathbf{2 0 1 5}$

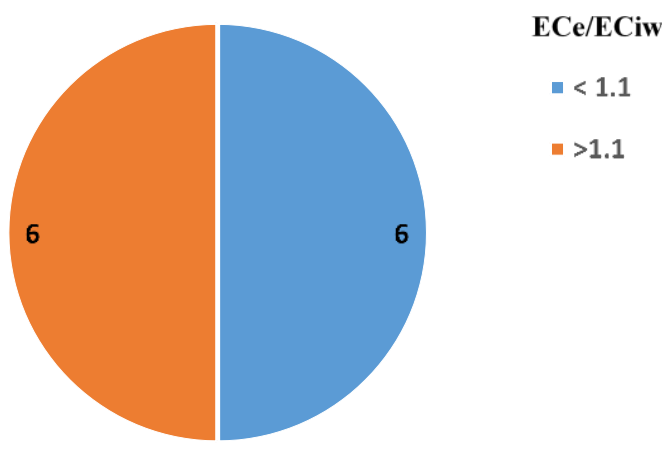

Figure 6. Assessment of salinity management efforts in 2015 (ECe/ECiw > 1.1) in A. ampliceps trees.

Tree rootzone salinity assessment in Acacia ampliceps in 2016

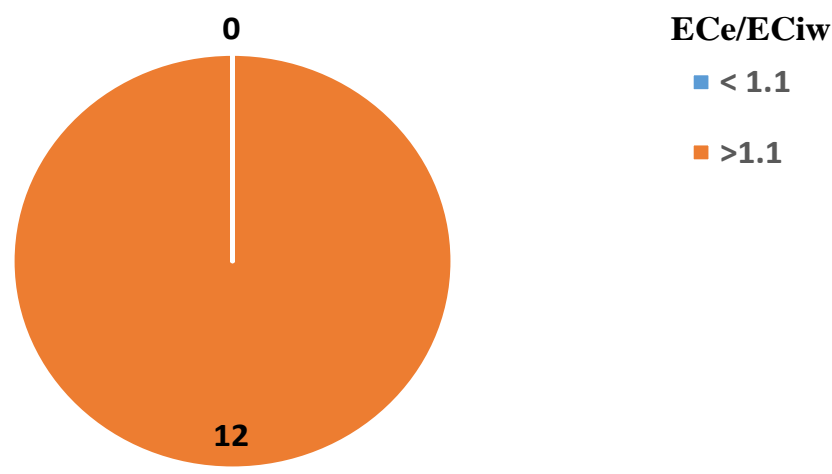

Figure 7. Assessment of salinity management efforts in 2016 (ECe/ECiw > 1.1) in A. ampliceps trees.

2016) when ECe/ECiw $>1.1$ scenario is used (Figures 5 to 7). Of 12 trees assessed, 8 (Figure 5), 6 (Figure 6), 0
(Figure 7) trees show salinity well managed in the years 2014, 2015 and 2016, respectively. 
Tree rootzone salinity assesment in $A$. ampliceps trees in 2014

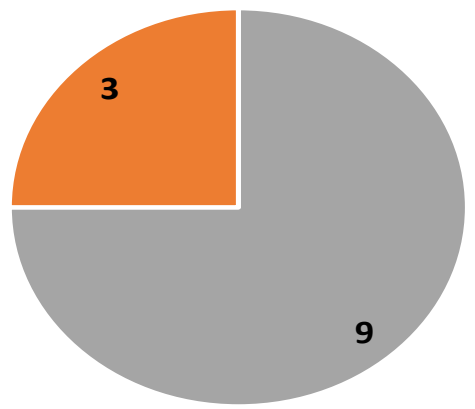

\section{ECe/ECiw}

$\because<1.5$

$\square>1.5$

Figure 8. Assessment of salinity management efforts in 2014 (ECe/ECiw $>1.5)$ in A. ampliceps trees.

Tree rootzone salinity assessment in A. ampliceps in 2015

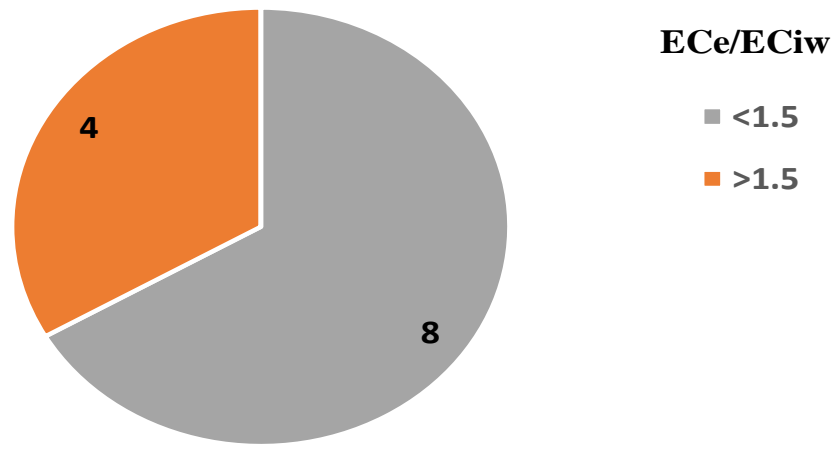

Figure 9. Assessment of salinity management efforts in 2015 (ECe/ECiw > 1.5) in A. ampliceps trees.

Tree root zone salinity assessment in A. ampliceps in 2016

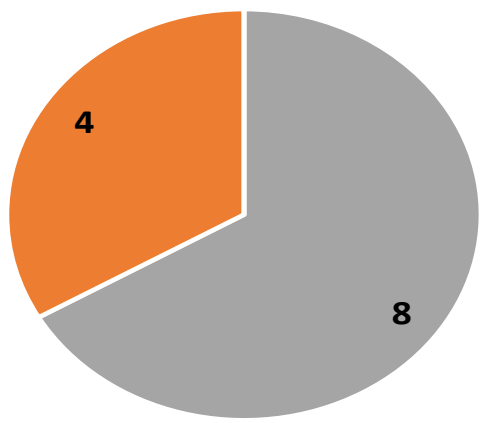

ECe/ECiw

$-<1.5$

$>1.5$

Figure 10. Assessment of salinity management efforts in 2016 (ECe/ECiw $>1.5$ ) in A. ampliceps trees.

When the criteria were relaxed $(\mathrm{ECe} / \mathrm{ECiw}>1.5)$ the results significantly improved, such as, of 12 trees, 9
(Figure 8), 8 (Figure 9), 8 (Figure 10) trees were found to be well managed soil salinity in the years 2014, 2015 and 
2016 respectively. The numerals in the figures show number of trees from where soil samples were collected and analyzed for soil salinity assessment.

\section{CONCLUSIONS AND RECOMMENDATIONS}

From the above observations, three conclusions are drawn, i) root zone salinity in $A$. ampliceps can be successfully managed with proper leaching fraction, using different irrigation water salinities; ii) the scenario $\mathrm{ECe} / \mathrm{ECw}>1.5$ fits well to assess salinity management efforts in sandy soil covering over $75 \%$ of the UAE; iii) the study has revealed potential of $A$. ampliceps adoption where saline/brackish water is the only option for irrigation and biomass is needed to feed sheep and goats.

\section{REFERENCES}

Allen RG, Pereira LS, Raes D, Smith M (1998). Crop evapotranspiration: Guidelines for computing crop requirements. Irrigation and Drainage Paper No. 56. Food and Agriculture Organization of the United Nations, Rome, Italy.

Glenn EP, Brown JJ, Blumwald E (1999). Salt tolerance and crop potential of halophytes. Crit. Rev. Plant Sci. 18:227-255.

Maas EV, Hoffman GJ (1977). Crop salt tolerance - current assessment. Journal of Irrigation and Drainage Division, ASCE 103. (IR2):115-134.

Malcom CV (1996). The Australian national programme for productive use of saline land as a model for national and international actions. In 'Halophytes and Biosaline Agriculture'. (Eds R Choukr-Allah, CV Malcolm, A Hamdy) pp. 275-295. (Marcel Dekker Inc. New York).

Masters D, Benes SR, Norman H (2007). Biosaline agriculture for forage and livestock production. Agric. Ecosyst. Environ. 119:234248.

Pasternak D, Nerd A, Demalach Y (1993). Irrigation with brackish water under desert conditions. IX. The salt tolerance of six forage crops. Agric. Water Manage. 24:321-334.

Peacock JM, Ferguson ME, Alhadrami GA, McCann IR, Al Hajoj A, Saleh A, Karnik R (2003). Conservation through utilization: a case study of the indigenous forage grasses of the Arabian Peninsula. J. Arid Environ. 54:15-28.

Qadir M, Quillerou E, Nangia V, Murtaza G, Singh M, Thomas RJ, Drechsel P, Noble AD (2014). Economics of salt-induced land degradation and restoration. Nat. Resour. Forum. 38:1-13.

Rao NK, McCann I, Shahid SA, Butt K, Al Araj B, Smail I (2017). Sustainable use of salt-degraded and abandoned farms for forage production using halophytic grasses. Crop Pasture Sci. 68:483-492. http://dx.doi.org/10.1071/CP16197.

Shahid SA (2013). Developments in salinity assessment, modeling, mapping, and monitoring from regional to submicroscopic scales. Chapter 1, In: Developments in Soil Salinity Assessment and Reclamation-Innovative Thinking and Use of Marginal Soil and Water Resources in Irrigated Agriculture (Shahid SA, Abdelfattah MA, Taha FK (eds.) Springer Dordrecht Heidelberg New York London, pp. 3-43.

Shahid SA (2014). Irrigation-induced soil salinity under different irrigation system - Assessment and management. Climate Change Outlook and Adaptation- An Int. J. 1(1):19-24

Shahid SA, Abdelfattah MA (2008). Soils of Abu Dhabi Emirate. In Richards Perry (Ed), Terrestrial Environment of Abu Dhabi Emirate: pp. 71-91.

Shahid SA, Rahman K (2011). Soil salinity development, classification, assessment and management in irrigated agriculture. In Handbook of Plant and Crop Stress, $3^{\text {rd }}$ Edition, Passarakli M (Ed) CRC, pp. 23-39.
Shahid SA, Dakheel A, Mufti KA, Shabbir G (2008). Automated in-situ soil salinity logging in irrigated agriculture. Eur. J. Sci. Res. 26(2):288-297.

Shahid SA, Abdelfattah MA, Omar SAS, Harahsheh H, Othman Y, Mahmoudi H (2010). Mapping and monitoring of soil salinization in remote sensing, GIS, electromagnetic induction and conventional methods - case studies. In Proc Int. Conf. Soil Salinization and Groundwater Salinization in Arid Regions, Sultan Qaboos Univ Muscat Oman, 11-14 Jan., 2010 (Ahmed M, Al-Rawahy SA (eds.)). Keynote papers and Abstracts, 1:59-97.

Shahid SA, Taha FK, Ismail S, Dakheel A, Abdelfattah MA (2011). Turning adversity into advantage for food security through improving soil quality and providing production systems for saline lands: ICBA perspectives. In Sustainable Agricultural Development: Recent Approaches in Resources Management and EnvironmentallyBalanced Production Enhancement (Behnassi M, Shahid SA, Silva JD (Eds) Springer pp.43-67.

Shahid SA, Alshankiti A, Mahmoudi H, Gill S, Sulit R, Naeem KH (2013). UAE agricultural strategy - soil resources and salinity diagnostics in agricultural farms (Annex). ICBA prepared on behalf of UAE Ministry of Environment and Water. pp. 27-29.

Shahid SA, Abdelfattah MA, Wilson MA, Kelley JA, Chiaretti JV (2014). United Arab Emirates Keys to Soil Taxonomy. Published by Springer. p. 108

Shahid SA, Zaman M, Heng L (2018a). Introduction to soil salinity, sodicity and diagnostics techniques. pp. 1-42. Chapter 1, In: M Zaman et al., Guideline for salinity assessment, mitigation and adaptation using nuclear and related techniques, Springer, https://doi.org/10.1007/978-3-319-96190-3_1.

Shahid SA, Zaman M, Heng L (2018b). Salinity and sodicity adaptation and mitigation options. pp. 55-89. Chapter 3, In: M. Zaman et al., Guideline for salinity assessment, mitigation and adaptation using nuclear and related techniques, https://doi.org/10.1007/978-3-31996190-3 1

Shahid SA, Zaman M, Heng L (2018c). Soil salinity: Historical perspectives and world overview of the problem. Chapter 2: In Zaman et al., 2018 Guidelines for salinity assessment, mitigation and adaptation using nuclear and related techniques. Springer. pp. 43-53.

Soil Science Division Staff (2017). Soil Survey Manual. USDA Handbook No 18.

Soil Survey Staff (2014a). Keys to soil taxonomy, 12th edition. USDANatural Resources Conservation Service.

Soil Survey Staff (2014b). Kellogg Soil Survey Laboratory methods manual. Soil Survey Investigations Report No. 42, version 5.0. R. Burt and Soil Survey Staff (eds.). USDA Natural Resources Conservation Service.

UNU-INWEH (2014). https://unu.edu/media-relations/releases/worldlosing-2000-hectares-of-farm-soil-daily-to-saltinduceddegradation.html (Last accessed May, 2019)

US Salinity Lab Staff (1954). Diagnosis and improvement of saline and alkali soils. Handbook 60. United States Department of Agriculture. p.160.

World Bank (2007). Making the most of scarcity: accountability for better water management in the Middle East and North Africa. (World Bank: Washington, DC).

Zaman M, Shahid SA, Heng L (2018a). Irrigation systems and zones of salinity development. pp. 91-111. Chapter 4, In: M. Zaman et al., Guideline for salinity assessment, mitigation and adaptation using nuclear and related techniques, Springer, https://doi.org/10.1007/9783-319-96190-3 1.

Zaman M, Shahid SA, Heng L (2018b). Irrigation water quality. Chapter 5: In Zaman et al., 2018 Guidelines for salinity assessment, mitigation and adaptation using nuclear and related techniques. Springer. pp. 113-131.

https://www.worldweatheronline.com/dubai-weatheraverages/dubai/ae.aspx.

http://www.sciencewebpublishing.net/jacr 